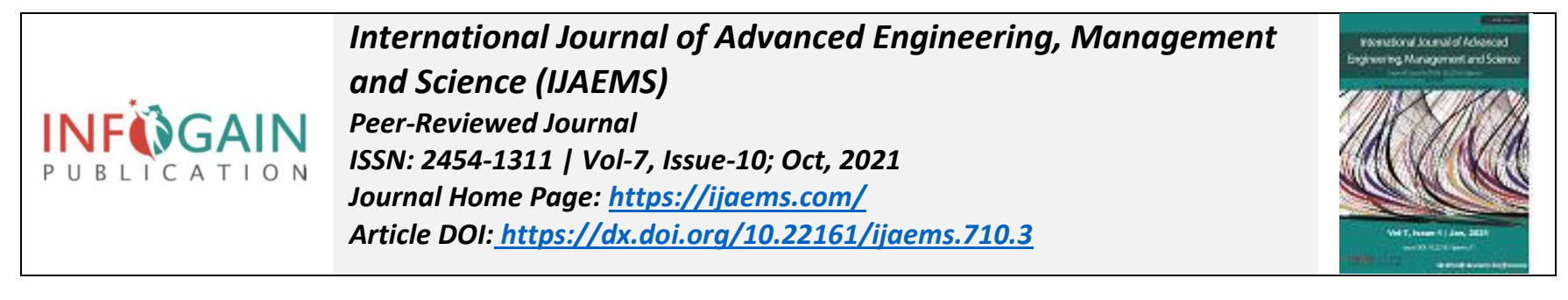

\title{
The role of sophisticated accounting system in organizational planning
}

\author{
Khowanas Saeed Qader ${ }^{1}$, Hawkar Anwar Hamad ${ }^{2}$, Bayar Gardi ${ }^{3}$, Pshdar Abdalla \\ Hamza $^{4}$, Dr. Govand Anwar ${ }^{5}$
}

\begin{abstract}
${ }^{1,2}$ Department of Accounting and Finance, College of Administrations and Economics, Lebanese French university, Kurdistan region, Iraq. ${ }^{3}$ Department of Accounting, College of Administration and Financial Sciences, Knowledge University, Kirkuk Road, 44001 Erbil, Kurdistan Region, Iraq.

${ }^{4}$ Department of Business Administration, Kurdistan Technical Institute, Sulaymaniyah, Iraq.

${ }^{5}$ Business Administration, Global University of Erbil, Kurdistan region, Iraq.
\end{abstract}

Received: 11 Sep 2021; Received in revised form: 15 Oct 2021; Accepted: 21 Oct 2021; Available online: 28 Oct 2021

\begin{abstract}
The aim of the current study is to analyze the relationship between accounting system and organizational planning. Managers are aware of their own requirements as well as the resources that their organizations would require to support the activities that have been recommended. We believe that the findings of this study will assist managers in better understanding different personality profiles and making decisions on which profile is most appropriate for their needs. The finding revealed that there is a positive relationship between accounting system and organizational planning. The study was carried out among car dealerships in Erbil, Kurdistan. Total of 53 participants involved in this study. Five point likert scales was used in this study ranging from not important at all to very important. However, despite the fact that this study regards organizational planning and accounting system as two distinct problems, the cluster analysis takes these two aspects into account at the same time. While the effect of organizational planning on the accounting system, and vice versa, was not specifically addressed in the current study, it is a relationship that should be explored in greater detail in future research.
\end{abstract}

Keywords-Accounting System, Strategy, Organizational Planning, Erbil.

\section{INTRODUCTION}

Recent decades have seen an increase in the volatility and unpredictability of the economic environment, and the complexity of company management has increased in tandem (Gardi, 2021). Increased competition, in particular, has posed a danger to the long-term viability of firms in particularly susceptible industries (Qader et al. 2021). When operating in this business environment, organizational planning with an eye on attaining organizational efficacy is very essential (Ismael et al. 2021). Although the formulation of successful strategies is important, it will not guarantee that an entity will attain organizational effectiveness unless and until the entity has put such plans into action (Ali et al. 2021). According to Hamad et al. (2021), this implementation necessitates the interposition of a specific form of organizational planning between the formulation of policies and their implementation (Fatah et al. 2021); furthermore, the effective implementation of the formulated strategies necessitates the use of instruments that facilitate and control the effective implementation of the formulated strategies (Ali \& Hamad, 2021). To effectively manage the business and achieve organizational efficacy, the organization takes a number of factors into consideration, including organizational structure, management style (Hamad, 2018), and the management control system, which includes the management accounting system (Ali \& Anwar, 2021). Among the main mechanisms responsible for the creation and execution of strategies is the management control system, which is particularly essential (Anwar \& Shukur,2015). The supply of management information that feeds the planning and control processes is essential in terms of breadth and dependability of the information (Hamza et al. 2021). There are two dimensions to such a management control system: I information selection; and, (ii) information 
display. (Sabir et al. 2021). In the first instance, it is necessary to pick the most relevant management accounting information (Aziz et al. 2021). The second refers to the management control techniques that organizations have adopted, including traditional ones such as organizational planning and accounting system (Sorguli et al. 2021). The design of the management control system is determined by the connection between these two aspects of the management control system (Ahmed et al. 2021).

The purpose of this study is to investigate how the characteristics of the information provided by the management accounting system influence the selection of management control procedures (Anwar \& Abdullah, 2021). Premise of this investigation is that the planning process, which encompasses both organizational planning and accounting system, differs depending on the accounting profile tools that a company chooses to use (Abdullah \& Anwar, 2021). Some firms implement all of the tools in accordance with the conceptual framework, whilst others have less-developed profiles in terms of the tools implemented by them (Anwar \& Shukur, 2015).

Anwar \& Abd Zebari, (2015) found that companies utilize more recently created accounting tools less frequently than they do older accounting tools. In this study, neither organizational planning nor accounting system are considered to be newly produced instruments for the sake of this investigation (Anwar \& Surarchith, 2015). The investigation is not only concerned with whether or whether they exist in a certain organization, but also with the extent to which they do so (in terms of complexity and usage profiles) (Anwar, 2017). Anwar \& Louis, (2017) argue that it is necessary to examine the reciprocal implications of the dimensions of the management control system in order to have an understanding of the relationship between them. In certain cases, the identification of the characteristics' profile can explain significant variations between entities in terms of the planning process (Anwar, 2015), the degree of usage, and even their level of pleasure with the use of the artifact (Hameed \& Anwar, 2018). The purpose of this study is to contribute to the literature by conducting a qualitative discussion of the planning process in a more ambitious dimension than simply determining whether the process exists or not, and by determining whether different planning process profiles necessitate different characteristics of the management accounting system (Abdullah et al. 2017). As a result of this associative analysis, the evolution of management accounting as well as the need for management accounting may be understood in a more comprehensive manner (Anwar \& Balcioglu, 2016). The following research topic is intended to be addressed in light of the fact that management accounting may have varied profiles of level of structuring and that, depending on these profiles, management accounting may have varying implications on the strategic plan and accounting system (Anwar, 2016).

\section{LITERATURE REVIEW}

\section{Organizational planning process}

According to organizational planning literature, the use of a organizational planning process has a beneficial impact on profitability, and this has been the primary goal of organizational planning since at least the 1960s (Anwar, 2017). Although several studies have looked at the link between organizational planning and performance, they have come up with a variety of different findings (Anwar \& Ghafoor, 2017). These differences, according to Anwar \& Qadir, (2017), are the consequence of a combination of factors, including I inconsistent planning, (ii) disregarding environmental impacts, and (iv) faulty measurement methodologies. The final point to mention is the inadequacies of accounting data. Anwar \& Climis, (2017) argue that one explanation for the disparity is the use of accounting-based metrics, such as revenue, which they believe are a contributing factor. According to Anwar \& Louis, (2017), this lack of convergence is caused by two intrinsic flaws in accounting-based performance measures: I a lack of uniformity in accounting data; and (ii) a lack of availability of data for small businesses (Anwar, 2015). For example, in their study, Gardi, (2021) identified many hurdles to the implementation of formal organizational planning, including a lack of relevant and appropriate information, which is critical to the organizational planning process for firms that officially implement this approach. In this context, Qader et al. (2021) state that information management will be the most important organizational issue in the future, and that the organizational planning process must highlight the sorts of information that will support the company's strategic direction in order to be effective (Ismael et al. 2021). No process needs more coordination and information input than the planning process of a company or organization (Ali et al. 2021). The management team, it appears, need a significant amount of internal information to support its decision-making process, and it appears that each organization has its own configuration of requirements, timeliness, and specifics (Hamad et al. 2021). When selecting information, care must be taken to ensure that it meets the unique needs of the business, rather than being dictated by a mandate from outside the institution (Fatah et al. 2021). The majority of objections leveled at accounting information stem from a failure to design the information structure in accordance with the unique requirements or demands of the company. Rather than looking at probable causes for this, such as life cycle and 
cost-benefit analysis, the authors' primary focus is on ensuring that the information structure is readily available (Ali \& Hamad, 2021).

\section{Management accounting systems}

Accounting information systems are divided into two primary subsystems, according to Hamad, (2018): the financial subsystem and the management subsystem. These subsystems are not necessary independent of one another, and in an ideal case, integration and a linked database would exist between the two subsystems, according to them (Ali \& Anwar, 2021). There is the option of using the outputs of one subsystem as inputs for the other component. In a nutshell, these writers are in favor of the integration of financial accounting databases. Management accounting systems are a subset of a company's overall management control systems, which include financial accounting systems (Anwar \& Shukur,2015). Overall, management control is in place to guarantee that internal agents operate in line with the objectives of the company (Hamza et al. 2021). Management accounting information systems, in this context, are one of the most important control methods for determining if diverse operations are generating advantages for the business as a whole (Sabir et al. 2021). According to Aziz et al. (2021), stated that the accounting exists in administration primarily to support the creation and implementation of corporate strategy. Administrative processes, according to them, are cyclical in nature and consist of four phases: I the formulation of strategies; (ii) the communication of these strategies throughout the organization; (iv) the development of tactics and the implementation of these tactics in order to implement the strategies throughout the entire organization; and (v) the development of controls to monitor the implementation steps and to assess the success in achieving strategic objectives (Sorguli et al. 2021). The authors (Ahmed et al. 2021) also point out that accounting has a function to play in each of these stages. In the first step, accounting information serves as the foundation for financial analysis by assisting in the development of plans that are financially feasible for the organization (Anwar \& Abdullah, 2021). During the second phase, accounting reports are a key instrument for communicating the fundamental components of the strategy, and they should be reviewed regularly. After that, accounting information is used to help determine which tactical program will be most effective in helping the organization accomplish its goals in the third phase (Abdullah \& Anwar, 2021). The accounting department also has a significant impact on analyzing and reporting on management and business unit performance, particularly when it comes to determining standard expenses, expenditure accounting systems, and yearly profit goals (Anwar \& Shukur, 2015). Management accounting systems, as a result, have the potential to provide financial information related to costing products, services, and other items of interest to management in terms of planning, control, assignment, continuous improvement, and decision-making. Management accounting systems are used to cost products, services, and other items of interest to management (Anwar \& Abd Zebari, 2015). As a result, management accounting can provide the information necessary for both goal formulation during the strategy design phase and performance assignment throughout the performance evaluation process (Anwar \& Surarchith, 2015). The planning and control process, on the other hand, must take into account both financial and nonfinancial information (Anwar, 2017).

\section{Relationship between organizational planning and accounting system}

According to Anwar \& Louis, (2017), the organizational planning concept possesses the following characteristics: The term "organizational planning" refers to the process of developing long-term organizational objectives, mediumterm programs to achieve those objectives, short-term accounting systems and operational plans to ensure that the strategies are implemented (Anwar, 2015). The term "organizational planning" refers to the future consequences of current decisions; it is also a process that begins with setting organizational objectives, then defines the strategies and policies to achieve those objectives, and finally develops detailed plans to ensure that the strategies are implemented (Hameed \& Anwar, 2018). The accounting system is the mechanism that makes it possible for the strategic plan to achieve its goals (Abdullah et al. 2017). It is important to note that when establishing links, particularly the connection between long term plans and short-term accounting systems, the association between strategic issues and tactical issues becomes particularly relevant to the overall development of the planning system, avoiding either an ethereal approach (which lacks contact with business reality) (Anwar \& Balcioglu, 2016)or an exclusively tactical process (which lacks consideration of the overall strategic objectives of the company) (Anwar, 2016). Neither of these extremes gives the process with the balance it need to function properly (Anwar, 2017). It is generally accepted that a relationship exists between inability to demonstrate a positive link between organizational planning and performance and "a propensity not to highlight the importance of organizational planning," according to Anwar \& Ghafoor, (2017). Management accounting can therefore contribute to poor organizational planning, either as a result of insufficient or absent information, or as a result of inefficient use of information 
(Anwar \& Qadir, 2017). Anwar \& Climis, (2017) divides the most frequent organizational planning faults into three categories: I those that occur before the commencement of the elaboration (Anwar \& Louis, 2017); (ii) those that occur during the elaboration; and (iii) those that occur during the implementation. Anwar, (2015) lists among the errors in the first category the failure to prepare the ground for organizational planning inside the organization as well as the failure to schedule the system for the management and assessment of organizational planning. Defining the criteria and implementing them (Ismael et al. 2021). For the executive, it is critical to have the parameters, as well as the information system, in place to ensure that organizational planning is controlled and evaluated effectively (Ali et al. 2021). Success in organizational planning is therefore dependent on the ability to control and evaluate operations on the basis of management accounting techniques (which include accounting system and accounting systemary control) (Hamad et al. 2021). Management accounting may provide the essential assistance to the planning process as a whole if it is done properly. However, according to Ali \& Anwar, (2021), the accounting system (which serves as the managers' tactical instrument) must include all relevant assumptions, marketing plans, production plans, supplies and inventories (Anwar \& Shukur,2015), human resource plans, investment plans, and financial statement projections in addition to other information (Hamza et al. 2021).

\section{Relationship between management accounting and the planning process}

The management system's profile is determined by the approaches of management control that are chosen and implemented (Sabir et al. 2021). The characteristics of the information provided by the system are influenced by the methodologies used for organizational planning and accounting system, among other things. Using traditional management control information, Aziz et al. (2021) establish the existence of a link between conventional management control approaches, such as organizational planning and accounting system, and traditional management control data. Strategic planners, according to Sorguli et al. (2021), are disengaged from the day-to-day specifics of operations while creating strategy, presumably because they believe that information systems can provide them with all of the information they need. It becomes much more relevant if the company does not take steps to guarantee that managers receive the daily accurate information that only management accounting is capable of providing. As a result, even authors who are critical of organizational planning, such as Ahmed et al. (2021), acknowledge the importance of information in the formulation of strategies and the evaluation of their feasibility after execution. Opponents of the use of accounting data as a source of such information, whether to assist strategy formulation (Anwar \& Abdullah, 2021) or to assess business performance (Abdullah \& Anwar, 2021), do exist (Anwar \& Shukur, 2015). Facsimile information (including managerial information), according to Anwar \& Abd Zebari, (2015), is frequently constrained in the following ways:

- It often has a restricted scope and frequently misses out crucial non-economic and nonquantitative elements that are significant;

- This makes it difficult to make effective use of factual knowledge in the creation of strategies.

- This causes factual information to be used in strategy creation to be reduced because it is frequently received late.

- An unexpectedly large amount of factual information cannot be relied upon.

Having a sufficient supply of information becomes a matter of importance in the decision-making process in this environment; thus, changes in the type of information that management accounting has provided in recent years have resulted from this priority (Anwar \& Surarchith, 2015). According to Anwar, (2017), management accounting is critical because: the organizational planning exercise is expanded in order to establish strategies that would allow the firm to achieve its goals (Anwar \& Louis, 2017). These strategies frequently necessitate the use of critical information from management accounting (Anwar, 2015). Furthermore, Hameed \& Anwar, (2018) state that accounting supports planning, management, and decisionmaking through accounting systems and other financial criteria, but does not record current outcomes in a systematic manner or play a role in performance evaluation." In addition, these writers have said that a management accounting system can only be efficient if it is compatible with the aims and strategies of the business (Abdullah et al. 2017). The present study which draws on the research of Anwar \& Balcioglu, (2016) as a theoretical foundation places a strong emphasis on the categorization of management accounting in terms of its characteristics. On the basis of Statement of Accounting Concept, these writers grouped the important qualities of management accounting into two areas: information selection and information presentation which they proposed should be divided into two divisions (Anwar, 2016). The first, information selection, is comprised of the content dimensions or tools that accounting systems employ to assist managers in their decision-making processes (Hamza et al. 2021). However, in light of the fact that organizations can differ in terms of strategies, structures, and styles, information presentation includes other attributes of accounting, such as the level of aggregation, the integration 
of information, the scope of the information, and the timeliness of information (Sabir et al. 2021).

\section{Research Methodology}

The purpose of this research is to examine the relationship between accounting system and organizational planning. The study was carried out among car dealerships in Erbil,
Kurdistan. Total of 53 participants involved in this study. Five point likert scales was used in this study ranging from not important at all to very important.

\section{Research Hypothesis}

Research Hypothesis: Accounting system management has a significant influence on organizational planning.

\section{DATA ANALYSIS}

Table 1- Demographic Analysis

\begin{tabular}{|c|c|c|c|}
\hline Items & Scales & Frequency & Percent \\
\hline \multirow[t]{4}{*}{ Gender } & Male & & \\
\hline & & 30 & 55.6 \\
\hline & Female & & \\
\hline & & 24 & 44.4 \\
\hline \multirow{9}{*}{ Age } & $20-29$ & & \\
\hline & & 18 & 33.3 \\
\hline & & & \\
\hline & $30-39$ & & \\
\hline & & 17 & 31.5 \\
\hline & $40-49$ & & \\
\hline & & 13 & 24.1 \\
\hline & $50-59$ & & \\
\hline & & 6 & 11.1 \\
\hline \multirow[t]{3}{*}{ Education } & & & \\
\hline & Bachelor & 45 & 83.3 \\
\hline & Master & 9 & 16.7 \\
\hline \multirow{5}{*}{ Experience } & Less than one & 9 & 16.7 \\
\hline & & & \\
\hline & $1-5$ & 26 & 48.1 \\
\hline & $6-10$ & 17 & 31.5 \\
\hline & 11 and over & 2 & 3.7 \\
\hline
\end{tabular}

The above table (1) demonstrates the participants" demographic analysis participated in this research. In regard of the participants ' gender; $55.6 \%$ of the participants were male while $44.4 \%$ of the participants were female. In regard of the participants' age; $33.3 \%$ of the participants were from 20-29 years old, $31.5 \%$ of the participants were 30-39 years old, $24.1 \%$ of the participants were $30-39$ years old, $11.1 \%$ of the participants were from 50-59 years old. In regard of the participants' level of education; $83 \%$ of the participants had bachelor degree and only $16.7 \%$ of the participants had Master degree. In regard of the participants" experience(s) $16.7 \%$ of the participants had less than one year of experience, $48.1 \%$ of the participants had $1-5$ years of the experiences, $31.5 \%$ of the participants had 6-10 years of the experiences and only $3.7 \%$ of the participants had 11 years and over of the experiences. 
Table 2- Reliability Tests

\begin{tabular}{|c|c|c|}
\hline Items & Cronbach's Alpha & Number of Items \\
\hline Accounting system & .849 & 10 \\
\hline Organizational Planning & .775 & 10 \\
\hline
\end{tabular}

The above table (2) shows the reliability test of 10 items for accounting systemand 10 items for organizational planning. The Cronbach's Alpha for ten Accounting system's ten items $=.849$ which is greater than .6 this means that ten items used for accounting systemfactor were reliable for this study and the Cronbach's Alpha for ten organizational planning 's ten items $=.775$ which is greater than .6 this means that ten items used for organizational planning factor were reliable for this study.

Table 3-Correlations Analysis

\begin{tabular}{l|l|c|c}
\hline Factors & Pearson Correlation & Accounting system & Organizational Planning \\
\hline \multirow{2}{*}{ Accounting system } & Pearson Correlation & 1 & $.858^{* *}$ \\
\cline { 2 - 4 } & Sig. (2-tailed) & & .000 \\
\cline { 2 - 4 } & $\mathrm{N}$ & 54 & 54 \\
\hline Organizational Planning & Pearson Correlation & $.858^{* *}$ & 1 \\
\cline { 2 - 4 } & Sig. (2-tailed) & .000 & 54 \\
\cline { 2 - 4 } & $\mathrm{N}$ & 54 & 5 \\
\hline
\end{tabular}

**. Correlation is significant at the 0.01 level (2-tailed).

The above table (3) shows the correlation analysis between accounting systemand organizational planning. The value of Pearson Correlation $=.858^{* *}$ which is greater than 0.01 this means that there is a positive and strong correlation between accounting system and organizational planning.

Table 4- Model Summary

\begin{tabular}{|c|c|c|c|c|}
\hline Model & $\mathrm{R}$ & R Square & Adjusted R Square & Std. Error of the Estimate \\
\hline 1 & $.858^{\mathrm{a}}$ & .736 & .731 & .39631 \\
\hline \multicolumn{5}{|c|}{ a. Predictors: (Constant), Accounting system } \\
\hline
\end{tabular}

The above table (4) shows the value of $\mathrm{R}$ Square $=.736$ which means that $73 \%$ of the variables are explained in this study.

Table 5- ANOVA

\begin{tabular}{|c|c|c|r|c|c|c|}
\hline \multicolumn{1}{|c|}{ Model } & Sum of Squares & df & Mean Square & F & Sig. \\
\hline \multirow{4}{*}{$1 \quad$ Regression } & 22.808 & 1 & 22.808 & 145.220 & $.000^{\mathrm{b}}$ \\
\cline { 3 - 7 } & Residual & 8.167 & 52 & .157 & & \\
\hline
\end{tabular}

a. Dependent Variable: Organizational Planning

b. Predictors: (Constant), Accounting system

The above table (5) shows the value of $\mathrm{F}$ for both variables (accounting system and organizational planning) is $145.220>1$ which indicates there is a significant association between both variables. 
Table 6-Coefficients

\begin{tabular}{|c|c|c|c|c|c|}
\hline \multirow{2}{*}{ Model } & \multicolumn{2}{|l|}{ Unstandardized Coefficients } & $\begin{array}{c}\text { Standardized } \\
\text { Coefficients }\end{array}$ & $\mathrm{t}$ & \multirow{2}{*}{ Sig. } \\
\cline { 2 - 5 } & $\mathrm{B}$ & Std. Error & Beta & & .270 \\
\hline (Constant) & .278 & .250 & & 1.115 & .000 \\
\hline
\end{tabular}

a. Dependent Variable: Organizational Planning

The above table (6) shows the value of Beta $=.858$ which is greater than 0.01 this indicates that there is a positive relationship between accounting system and organizational planning.

\section{CONCLUSION}

Despite the fact that the management literature regularly alludes to an anticipated link between the planning process (planning and accounting) and management accounting features, few (if any) studies have produced real data to support or refute this assumption. When it came to creating their organizational planning, the researchers investigated the hypothesis that there is a link between the management accounting systems employed by these firms and their conceptual adherence. It has been determined by this investigation that one of the most important conclusions to be drawn is that improper configuration of the planning process is caused by improper configuration of the management accounting attributes. Managers are aware of their own requirements as well as the resources that their organizations would require to support the activities that have been recommended. We believe that the findings of this study will assist managers in better understanding different personality profiles and making decisions on which profile is most appropriate for their needs. The finding revealed that there is a positive relationship between accounting system and organizational planning. However, despite the fact that this study regards organizational planning and accounting system as two distinct problems, the cluster analysis takes these two aspects into account at the same time. While the effect of organizational planning on the accounting system, and vice versa, was not specifically addressed in the current study, it is a relationship that should be explored in greater detail in future research.

\section{REFERENCES}

[1] Sorguli, S., B. Gardi, B. J. Othman, H. M. Aziz, S. A. Ahmed, B. Y. Sabir, N. B. Ismael, P. A. Hamza, B. J. Ali, and G. Anwar.(2021). "Innovation: Knowledge Management in the Innovating Industries, 6 (3), 10-23."
[2] Anwar, K., \& Louis, R. (2017). Factors Affecting Students' Anxiety in Language Learning: A Study of Private Universities in Erbil, Kurdistan. International Journal of Social Sciences \& Educational Studies, 4(3), 160.

[3] Ali, B. J., \& Anwar, G. (2021). The mediation role of change management in employee development. Ali, BJ, \& Anwar, G.(2021). The Mediation Role of Change Management in Employee Development. International Journal of English Literature and Social Sciences, 6(2), 361-374.

[4] Aziz, HM, Othman, BJ, Gardi, B., Ahmed, SA, Sabir, BY, Ismael, NB, Hamza, PA, Sorguli, S., Ali, BJ, Anwar, G.(2021). Employee Commitment: The Relationship between Employee Commitment And Job Satisfaction. Journal of Humanities and Education Development, 3(3), 54-66.

[5] Hameed, A. A., \& Anwar, K. (2018). Analyzing the Relationship between Intellectual Capital and Organizational Performance: A Study of Selected Private Banks in Kurdistan. International Journal of Social Sciences \& Educational Studies, 4(4), 39.

[6] Abdullah, M. S., Toycan, M., \& Anwar, K. (2017). The cost readiness of implementing e-learning. Custos E Agronegocio On Line, 13(2), 156-175.

[7] Ismael, N. B., Sorguli, S., Aziz, H. M., Sabir, B. Y., Hamza, P. A., Gardi, B., \& Al-Kake, F. R. A. (2021). The Impact of COVID-19 on Small and Medium-Sized Enterprises in Iraq. Annals of the Romanian Society for Cell Biology, 2496-2505.

[8] He, P., Niu, H., Sun, Z., \& Li, T. (2020). Accounting index of COVID-19 impact on Chinese industries: A case study using big data portrait analysis. Emerging Markets Finance and Trade, 56(10), 2332-2349.

[9] Ali, B. J., \& Anwar, G. (2021). A study of knowledge management alignment with production management: A study of carpet manufacture in Kurdistan region of Iraq. Ali, BJ, \& Anwar, G.(2021). A Study of Knowledge Management Alignment with Production Management: a Study of Carpet Manufacture in Kurdistan Region of Iraq. International Journal of English Literature and Social Sciences, 6(2), 346-360. 
[10] Putra, Y. M. (2019). Analysis of Factors Affecting the Interests of SMEs Using Accounting Applications. Journal of Economics and Business, 2(3), 818-826.

[11] Ali, B. J., \& Anwar, G. (2021). Strategic leadership effectiveness and its influence on organizational effectiveness. International Journal of Electrical, Electronics and Computers, 6(2).

[12] Coyne, J. G., \& McMickle, P. L. (2017). Can blockchains serve an accounting purpose?. Journal of Emerging Technologies in Accounting, 14(2), 101-111.

[13] Ali, B. J., Saleh, P. F., Akoi, S., Abdulrahman, A. A., Muhamed, A. S., Noori, H. N., \& Anwar, G. (2021, May). Impact of Service Quality on the Customer Satisfaction: Case study at Online Meeting Platforms. In Ali, BJ, Saleh, Akoi, S., Abdulrahman, AA, Muhamed, AS, Noori, HN, Anwar, G.(2021). Impact of Service Quality on the Customer Satisfaction: Case study at Online Meeting Platforms. International journal of Engineering, Business and Management (Vol. 5, No. 2, pp. 65-77).

[14] Bebbington, J., Russell, S., \& Thomson, I. (2017). Accounting and sustainable development: Reflections and propositions. Critical Perspectives on Accounting, 48, 2134.

[15] Ali, B. J., \& Anwar, G. (2021). Organization citizenship behaviour as a determining Factor in Business outcome. Ali, BJ, \& Anwar, G.(2021). Organization citizenship behaviour as a determining Factor in Business outcome. International journal of Rural Development, Environment and Health Research, 5(2), 17-25.

[16] Pratama, F. A., Kaslani, K., Nurdiawan, O., Rahaningsih, N., \& Nurhadiansyah, N. (2020, March). Learning Innovation Using the Zahir Application in Improving Understanding of Accounting Materials. In Journal of Physics: Conference Series (Vol. 1477, No. 3, p. 032018). IOP Publishing.

[17] Garbowski, M., Drobyazko, S., Matveeva, V., Kyiashko, O., \& Dmytrovska, V. (2019). Financial accounting of Ebusiness enterprises. Academy of Accounting and Financial Studies Journal, 23, 1-5.

[18] Ismeal, B. A., Aziz, H. M., Sorguli, S., Qader, K. S., Sabir, B. Y., Hamza, P. A., ... \& Anwar, G. (2021). The Role of External Auditing in Reducing Creative Accounting Practices.

[19] Ali, B. J., \& Anwar, G. (2021). Project Management and Dynamic Work Environments: The relationship between Leadership in Dynamic Work Environments in Kurdistan.

[20] Ali, BJ, \& Anwar, G.(2021). Project Management and Dynamic Work Environments: The relationship between Leadership in Dynamic Work Environments in Kurdistan. International Journal of Civil, Mechanical and Energy Science, 7(3), 10-18.

[21] Hamza, P. A., Sabir, B. Y., Qader, K. S., Aziz, H. M., Ismeal, B. A., Sorguli, S., ... \& Anwar, G. (2021). Global financial markets: Factors influencing the global financial markets.

[22] Ali, B. J., \& Anwar, G. (2021). Implementation of ELearning System Readiness: The Effect of the Cost Readiness on Implementing E-Learning.
[23] Ali, BJ, \& Anwar, G.(2021). Implementation of e-learning system readiness: The effect of the cost readiness on implementing e-learning. International Journal of Electrical, Electronics and Computers, 6(3), 27-37.

[24] Ali, B. J., \& Anwar, G. (2021). Anxiety and Foreign Language Learning: Analysis of Students' Anxiety Towards Foreign Language Learning.

[25] Moşteanu, N. R., \& Faccia, A. (2020). Digital Systems and New Challenges of Financial Management-FinTech, XBRL, Blockchain and Cryptocurrencies. Quality-Access to Success Journal, 21(174), 159-166.

[26] Anwar, G., \& Abdullah, N. N. (2021). Inspiring future entrepreneurs: The effect of experiential learning on the entrepreneurial intention at higher education. International Journal of English Literature and Social Sciences, 6.

[27] Ali, B. J., \& Anwar, G. (2021). Business strategy: The influence of Strategic Competitiveness on competitive advantage. International Journal of Electrical, Electronics and Computers, 6(2).

[28] Ali, BJ, \& Anwar, G.(2021). Marketing Strategy: Pricing strategies and its influence on consumer purchasing decision. International journal of Rural Development, Environment and Health Research, 5(2), 26-39.

[29] Hall, M., \& O'Dwyer, B. (2017). Accounting, nongovernmental organizations and civil society:: The importance of nonprofit organizations to understanding accounting, organizations and society. Accounting, Organizations and Society.

[30] Ali, B. J., \& Anwar, G. (2021). Intellectual capital: A modern model to measure the value creation in a business. Ali, BJ, \& Anwar, G.(2021). Intellectual capital: A modern model to measure the value creation in a business. International journal of Engineering, Business and Management, 5(2), 31-43.

[31] Anwar, G., \& Shukur, I. (2015). the impact of recruitment and selection on job satisfaction: Evidence from private school in Erbil. International Journal of Social Sciences \& Educational Studies, 1(3), 4-13.

[32] Bonsón, E., \& Bednárová, M. (2019). Blockchain and its implications for accounting and auditing. Meditari Accountancy Research.

[33] Anwar, G., \& Abd Zebari, B. (2015). The Relationship between Employee Engagement and Corporate Social Responsibility: A Case Study of Car Dealership in Erbil, Kurdistan. International Journal of Social Sciences \& Educational Studies, 2(2), 45.

[34] Dillard, J., \& Vinnari, E. (2019). Critical dialogical accountability: From accounting-based accountability to accountability-based accounting. Critical Perspectives on Accounting, 62, 16-38.

[35] Fatah, N. A., Hamad, H. A., \& Qader, K. S. (2021). The Role of Internal Audit on Financial Performance Under IIA Standards: A Survey Study of Selected Iraqi Banks. QALAAI ZANIST SCIENTIFIC JOURNAL, 6(2), 1028-1048.

[36] Ali, D. J., \& Hamad, H. A. (2021). The role of the cash flow statement to provide accounting information for the financial decision-making process:(Case study 
International Islamic Bank of Kurdistan in the year 2018). QALAAI ZANIST SCIENTIFIC JOURNAL, 6(2), 870-887.

[37] HAMAD, H. (2018). Customer Satisfaction In Banking Sector: The Case In North Iraq, City Of Erbil.

[38] Olatunji, O. C., \& Ayodele, K. B. (2017). Impact Of Information Technology On Tax Administration In Southwest Nigeria. Archives of Business Research, 5(9), 139-150.

[39] Ali, B. J., \& Anwar, G. (2021). The Effect of Marketing Culture Aspects of Healthcare Care on Marketing Creativity. Ali, BJ, \& Anwar, G.(2021). The Effect of Marketing Culture Aspects of Healthcare Care on Marketing Creativity. International Journal of English Literature and Social Sciences, 6(2), 171-182.

[40] Khuntia, J., Saldanha, T. J., Mithas, S., \& Sambamurthy, V. (2018). Information technology and sustainability: Evidence from an emerging economy. Production and Operations Management, 27(4), 756-773.

[41] Ali, B. J., \& Anwar, G. (2021). An Empirical Study of Employees' Motivation and its Influence Job Satisfaction. Ali, BJ, \& Anwar, G.(2021). An Empirical Study of Employees' Motivation and its Influence Job Satisfaction. International Journal of Engineering, Business and Management, 5(2), 21-30.

[42] Oláh, J., Karmazin, G., Pető, K., \& Popp, J. (2018). Information technology developments of logistics service providers in Hungary. International Journal of Logistics Research and Applications, 21(3), 332-344.

[43] Anwar, G., \& Shukur, I. (2015). The Impact of Training and Development on Job Satisfaction: A Case Study of Private Banks in Erbil. International Journal of Social Sciences \& Educational Studies, 2(1), 65.

[44] Ali, B. J., \& Anwar, G. (2021). Factors Influencing the Citizens' Acceptance of Electronic Government. International journal of Engineering, Business and Management (IJEBM), 5.

[45] Nayyar, A., \& Singh, I. (2018). A comprehensive analysis of Goods and Services Tax (GST) in India. Indian Journal of Finance, 12(2), 57-71.

[46] Ali, B. J., \& Anwar, G. (2021). The balanced scorecard's evolution as a strategic mechanism at banking sectors. Ali, BJ, \& Anwar, G.(2021). The Balanced Scorecard'S Evolution as a Strategic Mechanism at Banking Sectors. International Journal of English Literature and Social Sciences, 6(1), 471-478.

[47] Anwar, G., \& Abdullah, N. N. (2021). The impact of Human resource management practice on Organizational performance. International journal of Engineering, Business and Management (IJEBM), 5.

[48] Abdullah, N. N., \& Anwar, G. (2021). An Empirical Analysis of Natural Gas as an Alternative Fuel for Internal Transportation. International Journal of English Literature and Social Sciences, 6(1).

[49] Tronchin, L., Manfren, M., \& Nastasi, B. (2018). Energy efficiency, demand side management and energy storage technologies-A critical analysis of possible paths of integration in the built environment. Renewable and Sustainable Energy Reviews, 95, 341-353.

[50] Anwar, G., \& Shukur, I. (2015). Job satisfaction and employee turnover intention: A case study of private hospital in Erbil. International Journal of Social Sciences \& Educational Studies, 2(1), 73.

[51] Anwar, G., \& Shukur, I. (2015). The Impact of Service Quality Dimensions on Students' Satisfaction. International Journal of Social Sciences \& Educational Studies, 76.

[52] Bebbington, J., \& Unerman, J. (2020). Advancing research into accounting and the UN sustainable development goals. Accounting, Auditing \& Accountability Journal.

[53] Lev, B. (2019). Ending the accounting-for-intangibles status quo. European Accounting Review, 28(4), 713-736.

[54] Anwar, G., \& Surarchith, N. K. (2015). Factors Affecting Shoppers' Behavior in Erbil, Kurdistan-Iraq. International Journal of Social Sciences \& Educational Studies, 1(4), 10.

[55] Pincus, K. V., Stout, D. E., Sorensen, J. E., Stocks, K. D., \& Lawson, R. A. (2017). Forces for change in higher education and implications for the accounting academy. Journal of Accounting Education, 40, 1-18.

[56] Ali, B. J., \& Anwar, G. (2021). Measuring competitive intelligence Network and its role on Business Performance. International Journal of English Literature and Social Sciences, 6(2).

[57] Bebbington, J., \& Unerman, J. (2018). Achieving the United Nations Sustainable Development Goals: an enabling role for accounting research. Accounting, Auditing \& Accountability Journal.

[58] Ostaev, G. Y., Khosiev, B. N., Nekrasova, E. V., Frantsisko, O. Y., Markovina, E. V., \& Kubatieva, L. M. (2019). Improving the methodology for assessing the efficiency of labor in organizations of the agroindustrial complex: strategic accounting and analysis. Indo American Journal of Pharmaceutical Sciences, 6(5), 9114-9120.

[59] Ali, B. J., \& Anwar, G. (2021). Self-Leadership Skills as Intangible Resources for Sustainable Competitive Advantage. Advanced Engineering Science, 46(1).

[60] Bebbington, J., Österblom, H., Crona, B., Jouffray, J. B., Larrinaga, C., Russell, S., \& Scholtens, B. (2019). Accounting and accountability in the Anthropocene. Accounting, Auditing \& Accountability Journal.

[61] Hein, L., Bagstad, K. J., Obst, C., Edens, B., Schenau, S., Castillo, G., ... \& Caparrós, A. (2020). Progress in natural capital accounting for ecosystems. Science, 367(6477), 514-515.

[62] Ali, B. J., \& Anwar, G. (2021). Academic Teaching Skills: Determining the Methods of Teaching to Undergraduate Students. Ali, BJ, \& Anwar, G.(2021). Academic Teaching Skills: Determining the methods of teaching to undergraduate students. International Journal of English Literature and Social Sciences, 6(3), 155-162.

[63] Cockcroft, S., \& Russell, M. (2018). Big data opportunities for accounting and finance practice and research. Australian Accounting Review, 28(3), 323-333. 
[64] Syahputri, Y., Pribadi, T., \& Dalimunthe, H. (2020). The Implementation of Liability Accounting on Managerial Performance in PT. Telkom Tbk, Medan Branch. Budapest International Research and Critics Institute (BIRCIJournal): Humanities and Social Sciences, 3(3), 23952402.

[65] Ali, BJ, \& Anwar, G.(2021). Employee Turnover Intention and Job Satisfaction. International Journal of Advanced Engineering, Management and Science, 7(6), 22-30.

[66] Andiola, L. M., Masters, E., \& Norman, C. (2020). Integrating technology and data analytic skills into the accounting curriculum: Accounting department leaders' experiences and insights. Journal of Accounting Education, 50, 100655.

[67] Ali, B. J., Anwer, R. N. A. D., \& Anwar, G. (2021). Private Hospitals' Service Quality Dimensions: The impact of Service Quality Dimensions on patients' satisfaction. Int. J. Med. Phar. Drug Re, 7.

[68] Hörisch, J., Schaltegger, S., \& Freeman, R. E. (2020). Integrating stakeholder theory and sustainability accounting: A conceptual synthesis. Journal of Cleaner Production, 275, 124097.

[69] Ali, B. J., \& Anwar, G. (2021). Stock Exchange Investment: A Study of Factors That Influence Stock Exchange Investment. Ali, BJ, \& Anwar, G.(2021). Stock Exchange Investment: A Study of Factors That Influence Stock Exchange Investment. International Journal of Engineering, Business and Management, 5(3), 39-46.

[70] Kaya, C. T., Türkyılmaz, M., \& Birol, B. (2019). Impact of RPA technologies on accounting systems. Muhasebe ve Finansman Dergisi, (82).

[71] Ali, B. J., \& Anwar, G. (2021). Work Engagement: How Does Employee Work Engagement influence Employee Satisfaction?. Ali, BJ, \& Anwar, G.(2021). Work Engagement: How Does Employee Work Engagement influence Employee Satisfaction, 10-21.

[72] He, P., Niu, H., Sun, Z., \& Li, T. (2020). Accounting index of COVID-19 impact on Chinese industries: A case study using big data portrait analysis. Emerging Markets Finance and Trade, 56(10), 2332-2349.

[73] Hamad, K. Q., Qader, K. S., \& Sharif, R. J. M. (2021). Effectiveness And Adequacy Of Disclosure Provisions In Tehran Stock Exchange. PalArch's Journal of Archaeology of Egypt/Egyptology, 18(08), 2379-2388.

[74] Ali, B. J., \& Anwar, G. (2021). Vocabulary Learning Strategies and Foreign Language Acquisition at Private Schools.

[75] Ali, BJ, \& Anwar, G.(2021). Vocabulary Learning Strategies and Foreign Language Acquisition at Private Schools. International Journal of English Literature and Social Sciences, 6(3), 163-173.

[76] Ali, BJ, \& Anwar, G.(2021). Anxiety and Foreign Language Learning: Analysis of students' anxiety towards Foreign language learning. International Journal of English Literature and Social Sciences, 6(3), 234-244.

[77] Sorguli, S., Hamza, P. A., Ismeal, B. A., Sabir, B. Y., Aziz, H. M., Qader, K. S., ... \& Gardi, B. (2021). Adaption of EFilling of Income Tax Returns in Kurdistan.
[78] Ali, B. J., \& Anwar, G. (2021). Real Estates Strategies: Analysis of Strategic Management Practices in Real Estate Companies.

[79] Sabir, B. Y., Qader, K. S., Hamza, P. A., Ali, B., Ismeal, S. S., Aziz, H. M., ... \& Anwar, G. (2021). Analysis of Accounting-Based Measures of Expected Returns: A Study of Private SME In Kurdistan.

[80] Ali, BJ, \& Anwar, G.(2021). Real Estates Strategies: Analysis of Strategic Management Practices in Real Estate Companies. International Journal of Rural Development, Environment and Health Research, 5(3), 35-48.

[81] Qader, K. S., Ismeal, B. A., Aziz, H. M., Hamza, P. A., Sorguli, S., Sabir, B. Y., ... \& Gardi, B. (2021). The Effect of Human Resources Management Skills on Accounting Information Quality in Kurdistan Public Sector. Journal of Humanities and Education Development (JHED), 3(3), 131-143.

[82] Ali, B. J., \& Anwar, G. (2021). Administrative Crisis: The Role of Effective Leadership Styles in Crisis Management. Ali, BJ, \& Anwar, G.(2021). Administrative Crisis: The Role of Effective Leadership Styles in Crisis Management. International Journal of Advanced Engineering, Management and Science, 7(6), 31-41.

[83] Aziz, H. M., Sorguli, S., Hamza, P. A., Sabir, B. Y., Qader, K. S., Ismeal, B. A., ... \& Gardi, B. (2021). Factors affecting International Finance Corporation. Journal of Humanities and Education Development (JHED), 3(3), 148-157.

[84] Ali, B. J., \& Anwar, G. (2021). Corporate Social Responsibility: The Influence of Employee Engagement on Corporate Social Responsibility. Journal of Humanities and Education Development (JHED), 3(3), 77-83.

[85] Ali, BJ, Gardi, B., Othman, BJ, Sabir, BY, Sorguli, S., Ismael, NB, Hamza, PA, Aziz, HM, Ahmed, AA, Anwar, G.(2021). The Role of Shopping Malls on Kurdistan Regional Government's Economy. Journal of Humanities and Education Development, 3(3), 39-53.

[86] Ali, B. J., \& Anwar, G. (2021). Porter's Generic Competitive Strategies and its influence on the Competitive Advantage. Ali, BJ, \& Anwar, G.(2021). Porter's Generic Competitive Strategies and its influence on the Competitive Advantage. International Journal of Advanced Engineering, Management and Science, 7(6), 42-51.

[87] Anwar, G., \& Abdullah, N. N. (2021). A Project Management Improvement Program: Enhancing Production With Implementing the Knowledge Management Principles. Advanced Engineering Science, 46(1).

[88] Aziz, H. M., Sorguli, S., Hamza, P. A., Sabir, B. Y., Qader, K. S., Ismeal, B. A., ... \& Gardi, B. (2021). Factors affecting International Finance Corporation. Journal of Humanities and Education Development (JHED), 3(3), 148-157.

[89] Anwar, K. (2017). Analyzing The Conceptual Model Of Service Quality And Its Relationship With Guests'satisfaction: A Study Of Hotels In Erbil. The 
International Journal of Accounting and Business Society, 25(2), 1-16.

[90] Ali, BJ, Gardi, B., Othman, BJ, Ismael, NB, Sorguli, S., Sabir, BY, Ahmed, SA, Hamza, PA, Aziz, HM, Anwar, G.(2021). Educational system: The policy of Educational system in Kurdistan Region in public Kindergarten. International Journal of English Literature and Social Sciences.

[91] Anwar, K. (2017). The Role of Effective Leadership in Crisis Management: Study of Private Companies in Kurdistan. Qalaai Zanist Scientific Journal, 2(4), 326-338.

[92] Anwar, K., \& Louis, R. (2017). Factors Affecting Students' Anxiety in Language Learning: A Study of Private Universities in Erbil, Kurdistan. International Journal of Social Sciences \& Educational Studies, 4(3), 160.

[93] Anwar, G. (2015, April). Vocabulary Learning Strategies Of English Language Learners In Northern Cyprus. In BOOK of PROCEEDINGS (p. 226).

[94] Gardi, B. (2021). The effects of computerized accounting system on auditing process: a case study from northern Iraq. Available at SSRN 3838327.

[95] Anwar, G., \& Shukur, I. (2015). Students' Attitudes towards Learning English Language in Erbil. International Journal of Social Sciences \& Educational Studies, 1(4), 17.

[96] Anwar, K., \& Balcioglu, H. (2016). The relationship between transformational leadership characteristics and effectiveness: A case study of construction companies in Erbil. International Journal of Science Technology and Management, 5(2), 250-256.

[97] Anwar, K. (2016). Comparison between cost leadership and differentiation strategy in agricultural businesses. Custos E Agronegocio on Line, 12(2), 212231.

[98] Gardi, B. (2021). Investigating the effects of Financial Accounting Reports on Managerial Decision Making in Small and Medium-sized Enterprises. Available at SSRN 3838226.

[99] Ali, BJ, Gardi, B., Othman, BJ, Ahmed, SA, Ismael, NB, Hamza, PA, Aziz, HM, Sabir, BY, Anwar, G.(2021). Hotel Service Quality: The Impact of Service Quality on Customer Satisfaction in Hospitality. International Journal of Engineering, Business and Management, 5(3), 14-28.

[100] Anwar, K. (2017). Leading Construction Project Teams: The Effectiveness of Transformational Leadership in Dynamic Work Environments in Kurdistan. International Journal of Advanced Engineering, Management and Science, 3(10), 239925.

[101] Ismael, NB, Othman, BJ, Gardi, B., Hamza, PA, Sorguli, S., Aziz, HM, Ahmed, SA, Sabir, BY, Ali, BJ, Anwar, G.(2021). The Role of Training and Development on Organizational effectiveness. International Journal of Engineering, Business and Management, 5(3), 15-24.

[102] Anwar, K., \& Ghafoor, C. (2017). Knowledge management and organizational performance: A study of private universities in Kurdistan. International Journal of Social Sciences \& Educational Studies, 4(2), 53.

[103] Anwar, K., \& Qadir, G. H. (2017). A Study of the Relationship between Work Engagement and Job
Satisfaction in Private Companies in Kurdistan. International Journal of Advanced Engineering, Management and Science, 3(12), 239944.

[104] Anwar, K. (2017). Factors affecting stock exchange investment in kurdistan. The International Journal of Accounting and Business Society, 25(1), 32-37.

[105] Ahmed, SA, Othman, BJ, Gardi, B., Sabir, BY, Ismael, NB, Hamza, PA, Sorguli, S., Aziz, HM, Ali, BJ, Anwar, G.(2021). Students' Attitudes towards Learning English in the Kurdistan region of Iraq. International Journal of English Literature and Social Sciences, 6(3), 072-087.

[106] Anwar, K., \& Climis, R. (2017). Analyzing the relationship between types of advertisement and customer choice: a study of retailer stores in erbil. The International Journal of Accounting and Business Society, 25(2), 43-52.

[107] Ali, B. J., \& Anwar, G. (2021). Measuring competitive intelligence Network and its role on Business Performance. International Journal of English Literature and Social Sciences, 6(2).

[108] Sabir, B. Y., Jabbar Othman, B., Gardi, B., Burhan Ismael, N., Abdalla Hamza, P., Sorguli, S., ... \& Anwar, G. (2021). Administrative Decentralization: The Transfer of Competency from The Ministry of Education to General Directorates. International Journal of Rural Development, Environment and Health Research (IJREH), 5.

[109] Ali, BJ, Anwar, G., Gardi, B., Othman, BJ, Aziz, HM, Ahmed, SA, Hamza, PA, Ismael, NB, Sorguli, S., Sabir, BY (2021). Business Communication Strategies: Analysis of Internal Communication Processes. Journal of Humanities and Education Development, 3(3), 16-38.

[110] Anwar, G. (2015, April). Vocabulary Learning Strategies Of English Language Learners In Northern Cyprus. In BOOK of PROCEEDINGS (p. 226).

[111] Hamza, P. A., Othman, B. J., Gardi, B., Sorguli, S., Aziz, H. M., Ahmed, S. A., ... \& Anwar, G. (2021). Recruitment and Selection: The Relationship between Recruitment and Selection with Organizational Performance. International Journal of Engineering, Business and Management, 5(3), $1-13$.

[112] Anwar, G., \& Shukur, I. (2015). Students' Attitudes towards Learning English Language in Erbil. International Journal of Social Sciences \& Educational Studies, 1(4), 17. 